\title{
Pyrolysis of Macroalgae and Polysytrene: A Review
}

\author{
Ketwalee Kositkanawuth • Melanie L. Sattler • \\ Brian Dennis
}

Published online: 20 September 2014

(C) Springer International Publishing AG 2014

\begin{abstract}
Aquatic biomass, especially algae, is a promising renewable energy resource, owing to its high growth rate, high oil content, and lack of competition with land needed for food crops. Both micro- and macroalgae can be converted to liquid fuel through pyrolysis; however, the high oxygen content of the oil results in a low calorific value. Co-pyrolysis of biomass with synthetic polymers can improve oil quantity and quality: the polymers are petroleum products, contain less oxygen, and provide a comparable high heating value to conventional fossil fuels. Polystyrene is a particularly attractive synthetic polymer, because it has the lowest recycling rate of the major categories of plastic. This article provides background concerning thermal conversion of biomass/organic waste to energy, focusing on pyrolysis. Advantages of algae and polystyrene as pyrolysis feedstocks are discussed, and previous pyrolysis studies of macroalgae and polystyrene, as well as co-pyrolysis studies of biomass and plastics, are reviewed.
\end{abstract}

Keywords Biomass $\cdot$ Algae $\cdot$ Polystyrene $\cdot$ Plastic $\cdot$ Pyrolysis $\cdot$ Energy $\cdot$ Alternative energy

K. Kositkanawuth

Department of Environmental Engineering, King Mongkut's

University of Technology Thonburi, 128 Pracha U-thit Rd.,

Thong Kru, Bangkok 10140, Thailand

e-mail: khingkha@hotmail.com

M. L. Sattler $(\square)$

Department of Civil Engineering, University of Texas at Arlington, Box 19308, Arlington, TX 76019, USA

e-mail: sattler@uta.edu

B. Dennis

Department of Mechanical and Aerospace Engineering, University of Texas at Arlington, Box 19023, Arlington, TX 76019, USA

e-mail: dennisb@uta.edu

\section{Introduction}

Several land biomass and fuel crops have been studied as potential sources for sustainable energy. A primary drawback of fuel crops such as corn, soybean, palm, and sunflower is competition with the food market. Therefore, researchers have started targeting aquatic biomass, especially algae, as a renewable energy source. Aquatic biomass poses several advantages in addition to no competition with land needed for food crops: the higher growth rate for many forms of aquatic biomass results in faster mass production, and problems associated with land use, such as fertilizer and pesticide pollution of storm water, are reduced.

Both micro- and macroalgae can be converted to liquid fuel through pyrolysis, which occurs in the absence of oxygen at high temperatures and yields three final products: liquid oil, gas, and solid residue. The main challenge in producing pyrolysis oil from biomass is the high oxygen content of the oil, which results in a low calorific value. Consequently, combining biomass with synthetic polymers is an option to improve oil quantity and quality, because the polymers are petroleum products, contain less oxygen, and provide a comparable high heating value to conventional fossil fuels. Polystyrene (PS) is a particularly attractive synthetic polymer, because it has the lowest recycling rate of the major categories of plastic.

This article first provides general background concerning thermal conversion of biomass/organic waste to energy, with a focus on pyrolysis. Advantages of algae and PS as pyrolysis feedstocks are then discussed, and previous studies of pyrolysis of macroalgae and PS are reviewed. Finally, previous studies of the co-pyrolysis of biomass and plastics are summarized.

\section{Thermal Conversion of Biomass/Organic Waste to Energy}

Either biological or thermal conversion is normally used to convert biomass or organic waste into useful energy, as shown 
in Fig. 1. Thermal conversion has recently gained more attention because it is much faster than biological processes; in addition, thermal processes can be used to obtain energy from certain wastes, such as plastics, which microbes cannot break down. Thermal conversion processes include direct combustion, gasification, pyrolysis, and liquefaction. Even though all thermal conversions have the same basic concept - using heat input to obtain useful energy/fuel output - the amount of air supply and the form of output energy/fuel for each process are quite different. For direct combustion, an excess amount of air is provided to the process, and then energy is produced in the form of heat. A partial amount of air is fed to gasification, while pyrolysis occurs in an absence of air. Syngas and bio-oil are fuel outputs obtained via gasification and pyrolysis, respectively. Liquefaction can be achieved under wet conditions; thus, the feedstock does not have to be dried prior to the process. Similar to pyrolysis, liquefaction produces a liquid product [1].

Among the thermal conversion processes, Demirbas (2002) illustrated that pyrolysis is the most efficient producing energy with high fuel-to-feed ratios [2]. Unlike the gas-phase products of direct combustion and gasification, bio-oil from pyrolysis is in the liquid phase; therefore, it is more convenient to store and transport. Pyrolysis takes places in the absence of oxygen, resulting in higher net calorific value, gas-phase products $\left(10-20 \mathrm{MJ} / \mathrm{Nm}^{3}\right)$ than gasification and combustion (4-15 MJ/ $\mathrm{Nm}^{3}$ ) [3]. Additionally, pyrolysis can be achieved at lower temperatures than combustion and gasification, resulting in less trace heavy metals and dioxin emissions in the gas stream [4]. Compared with pyrolysis, liquefaction occurs at lower temperatures but higher pressures [1]. However, not much attention has been paid to liquefaction because of the high cost of liquefaction reactors and fuelfeeding systems, as well as the need for a catalyst $[5,6]$.

\section{The Pyrolysis Process}

Pyrolysis, thermo-degradation of biomass or waste in the absence of oxygen, occurs from 400 to $700{ }^{\circ} \mathrm{C}$, and yields three final products: oil (30-75\%), residues or char $(10$ $35 \%)$, and non-condensable gases (10-35\%) such as CO, $\mathrm{CO}_{2}, \mathrm{H}_{2}$, and light hydrocarbons [7]. From an energy stand point, oil is the most attractive product from pyrolysis, because it can be used as liquid fuel for different purposes, such as combustion in stationary diesel engines and gasification. Nevertheless, pyrolysis oil is typically inappropriate for direct transportation use because of its low $\mathrm{pH}$ and high viscosity, which can lead to corrosion and severe engine deposition, respectively. Furthermore, the high oxygen content makes its heating value lower than conventional fuels. As a result, further upgrading and refining processes such as deoxygenation and hydrotreating are needed to improve the quality of pyrolysis oil [8].

Residues and non-condensable gases from pyrolysis are also useful. Moreno-Pirajan et al. (2010) created activated carbon from cow bone residues via pyrolysis, and then observed its adsorption capacity for copper $\left(\mathrm{Cu}^{2+}\right)$ and lead $\left(\mathrm{Pb}^{2+}\right)$ ions [9]. Mullen et al. (2010) also confirmed the use of residues for metal removal from drinking and wastewater [10]. They found that adsorbents made from corn cob and corn stover residues could adsorb up to 50 and $80 \%$, respectively of $\mathrm{Cu}^{2+}$ from solution. The authors also discussed using pyrolysis residues for soil amendment purposes or renewable solid fuel. Gas products can be circulated back to the process, and thus serve as an additional heating source or fluidizing gas in reactors. Park et al. (2008) and Jung et al. (2008) suggested that recirculating gas product back to the process helps enhance oil yield, compared with using only inert gas in the system $[11,12]$.

\section{Influence of Pyrolysis Operating Parameters on Product Yield}

Not only is technology important for pyrolysis, but operating parameters such as temperature, feed size, feed rate, gas flow rate, and residence time also influence products' quantity and quality. Heo et al. (2010) studied pyrolysis of waste furniture sawdust under various conditions of temperature, feed size,
Fig. 1 Conversion processes for biomass/waste

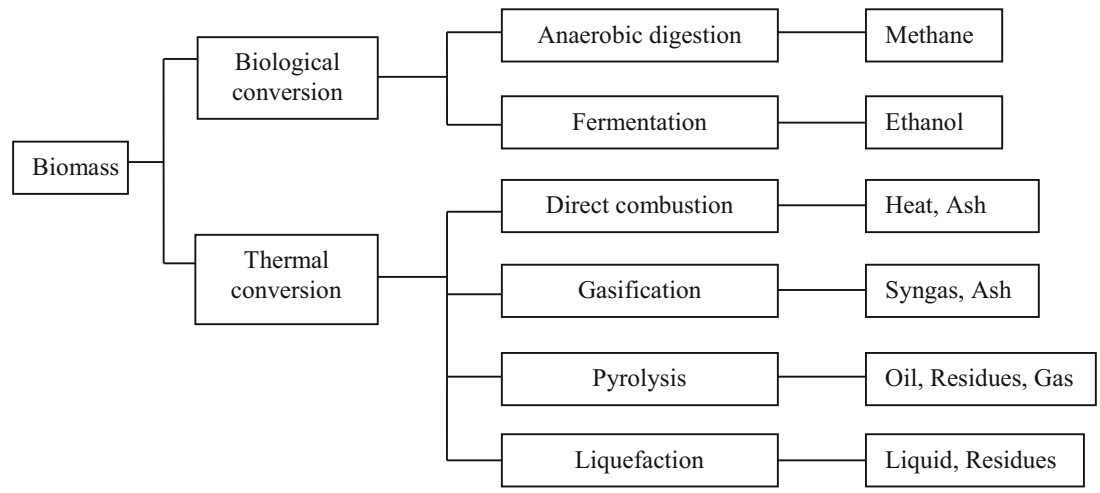


feed rate, and gas flow rate [13]. They found maximum bio-oil yield at $450^{\circ} \mathrm{C}$; at lower or higher temperatures, incomplete or secondary decomposition occurred, respectively. Larger or smaller feed sizes can both contribute to less oil product as a result of less heat transfer or particle overheating, respectively. Both feed rate and gas flow rate affected the vapor residence time inside the reactor. A lower rate provides a longer residence time for oil vapors, allowing them to react further and change into non-condensable gases, resulting in less oil yield. Park et al. (2008) and Jung et al. (2008) came to similar conclusions in studies of pyrolysis of Japanese larch sawdust, rice straw, and bamboo sawdust [11, 12].

Heo et al. (2010) and Park et al. (2008) indicated that the most significant parameter affecting characteristics of pyrolysis products is temperature [11, 13]. Garcia-Perez et al. (2008) also stated the importance of temperature on yield and compositions of bio-oil, char, and gases [14]. Sensoz and Kaynar (2006) studied the effect of temperature, heating rate, and particle size on pyrolysis of soybean cake; the results showed that particle size had an insignificant effect on product yield, while temperature and heating rate did influence product yields [15]. Aguiar et al. (2008) examined the influence of temperature and particle size on pyrolysis of orange peel residues and concluded that temperature has a greater effect on product yields than particle size [16].

\section{Advantages of Algae as a Pyrolysis Feedstock}

In recent years, algae have become more attractive as alternative fuel sources because they provide several advantages compared with terrestrial plants. Algae are mostly non-food crops; therefore, they will not compete with other uses in the market, unlike other biofuel feedstocks such as corn, palm, and peanuts. Algae would use over three times less farming area than corn, canola, and switch grass to meet the annual US energy consumption [17]. Algae grow faster than most seed crops, and the energy produced per hectare from algae can be 30-100 times greater than land crops [18].

In addition, algae can help reduce impacts from agricultural activities related to chemical uses such as fertilizers and pesticides. Lardon et al. (2009) compared life-cycle impacts of biodiesel from various feedstocks including algae, rapeseed, soybean, and palm [19]. Algae biodiesel showed the lowest impacts on eutrophication and land use because of smaller amounts of pesticides and fertilizers used.

Algae can also grow in marine water, freshwater, or even in wastewater treatment ponds [18]. Wang et al. (2010) found that green algae could grow well on wastewater collected from four different types of treatment units at a wastewater treatment plant; in addition, the algae removed up to $80 \%$ and $90 \%$ of total nitrogen and phosphorus, respectively, from the wastewater [20].
Most research has focused on microalgae pyrolysis because of its faster growth rate and productivity and higher lipid content. However, because microalgae are small-scale biomass, normally $3-30 \mu \mathrm{m}$ in diameter, they require highly efficient harvesting methods, which depend on species, cell density, and culture conditions, resulting in high capital and operating costs [21]. Demirbas (2010) also highlighted two main drawbacks of biofuel production using microalgae: low biomass concentration and small cell size, both of which increase the cost of harvesting [18]. Additionally, it is quite impractical to harvest microalgae from natural sources because it is time consuming and difficult to distinguish pure species. Consequently, macroalgae, including seaweed, can be another potential choice in biofuel production. Yu et al. (2008) mentioned seaweed, including red, green, and brown types, as a possible energy source, especially for coastal areas, because of their benefits of a short life cycle and a high productivity rate, like other algae [22].

Using seaweed macroalgae for pyrolysis would reduce problems associated with the seaweed's waste disposal. For example, Sargassum is a genus of marine brown macroalgae (Phaeophyceae) found in Asia, North America, Australia, and Europe. The tons of seaweed that deposit onto shorelines release unpleasant smells as they start to decompose, destroy the beach aesthetic for visitors, and can block the sea turtles from nesting and impact their egg hatching [23]. Energy recovery would be a more efficient use of this seaweed.

\section{Previous Studies of Pyrolysis of Macroalgae}

A number of previous studies have investigated the pyrolysis characteristics of macroalgae [24-28]. Several additional studies have compared pyrolysis of macroalgae with that of woody biomass:

- Wang et al. (2007) studied pyrolysis of a species of seaweed from China from room temperature to $1,200^{\circ} \mathrm{C}$ [29]. The seaweed started to release volatile materials earlier than wood biomass. In addition, the seaweed released some heat during the process, meaning that the seaweed requires less energy input.

- Ross et al. (2008) investigated the thermal behavior of five species of brown seaweed compared with three forms of terrestrial biomass [30]. In characterizing the seaweed products, the authors found a lower proportion of phenolic compounds compared with terrestrial biomass; this could be advantageous, because phenolic compounds pose a difficulty in the deoxygenation process needed to upgrade the oil.

- Li et al. (2010) found that land plants require higher pyrolysis temperatures than algae, likely owing to the 
cellulose, hemicellulose, and lignin components of land plants $[7,18,24,30]$.

- Bae et al. (2011) conducted pyrolysis of two brown and one red macroalgae between 300 and $600{ }^{\circ} \mathrm{C}$; the oil yields were comparable to conventional pyrolysis of land biomass [31]. The authors also calculated the heating value of the oil excluding water content, which proved to be comparable to the heating value of oil from wood biomass.

- Trinh et al. (2013) compared product distributions and energy recoveries from pyrolysis of lignin, macroalgae, and wood and straw [32•]. The macroalgae yielded 65 wt \% bio-oil on dry ash free basis (daf) and $76 \%$ energy recovery in the bio-oil, while the lignin yielded $47 \mathrm{wt} . \%$ daf bio-oil and energy recovery in bio-oil of $45 \%$. The higher heating value (HHV) of wood, straw, lignin, and algae oils were 24.0, 23.7, 29.7, and $25.7 \mathrm{MJ} / \mathrm{kg} \mathrm{db}$, respectively.

- Kebelmann et al. (2013) pyrolyzed macroalgal polar species from the Arctic region, Spitsbergen/Norway, and the Antarctic peninsula [33]. The maximum degradation temperatures for Prasiola crispa were observed within the range of $220-320^{\circ} \mathrm{C}$, which is lower than typically obtained by terrestrial biomass, owing to divergent polysaccharide compositions.

Several studies have attempted to optimize pyrolysis of macroalgae. Studying blue-green algae blooms, $\mathrm{Hu}$ et al. (2013) determined the effects of pyrolysis temperature, particle size, and sweep gas flow rate on pyrolysis product yields and bio-oil properties [34•]. The maximum oil yield of $54.97 \%$ was obtained at a pyrolysis temperature of $500{ }^{\circ} \mathrm{C}$, a particle size below $0.25 \mathrm{~mm}$, and a sweep gas flow rate of $100 \mathrm{~mL} / \mathrm{min}$. Ferrera-Lorenzo et al. (2014) used thermogravimetric analysis of a macroalgae meal to determine optimal pyrolysis conditions for obtaining energy from the char, oil, and gas, and for preparing adsorbent materials from the char [35]. The optimal conditions were: final temperature: $750{ }^{\circ} \mathrm{C}$; heating rate: $5^{\circ} \mathrm{C} / \mathrm{min}$, time at final temperature: $60 \mathrm{~min}$; flow of inert gas $\left(\mathrm{N}_{2}\right): 150 \mathrm{~mL} / \mathrm{min}$. The char obtained from the pyrolysis process presented properties that make it suitable as a solid fuel and as a precursor of activated carbon.

Kan et al. (2014) found no obvious differences in the thermal behavior between freshwater micro- and macroalgae, with similar thermogravimetric and apparent specific-heat profiles [36]. However, marine algae exhibited significantly different thermal behavior (endothermic) compared with the freshwater algae. The maximum oil conversion was $55 \mathrm{wt} \%$ for the marine algae, but $70-75 \mathrm{wt} \%$ for the freshwater algae.

\section{Advantages of Polystyrene as a Pyrolysis Feedstock}

According to the US Environmental Protection Agency (EPA), plastic waste represents about $12 \%$ of municipal solid waste and the consumption rate has been increasing rapidly [37]. Only $7 \%$ of the plastic waste was recycled in the US in 2008 while the rest was discarded [38]. Technical, economic, and quality challenges associated with recycling plastic waste include:

- many sorting and recycling technologies are still under development;

- waste volume needs to be sufficient to continuously supply commercial plants;

- recycled plastic is considered lower quality compared with virgin materials, owing to waste coming from various sources and possible contamination;

- additive components, including pigments and stabilizers, which may contain heavy metals and harmful substances [39].

Plastic waste is seldom biodegraded; therefore, it would permanently remain in a landfill and may cause groundwater contamination owing to chemical and additive components. Lazarevic et al. (2010) pointed out that landfilling is the least preferable method for plastic waste management [40]. Specifically, PS is lightweight and has a low density; therefore, it will occupy large volume in a landfill. Gu et al. (2010) mentioned that PS waste creates a large carbon footprint in being transported to a landfill because of its low density [41]. PS products mostly contain air; only about $5 \%$ of the volume of PS that is loaded onto trucks is actual PS.

Plastic is originally made from polymers, which are petroleum products; hence, it has a high heating value, comparable to fossil fuels. Consequently, energy recovery can be another option for managing discarded plastic waste. Incineration, the traditional thermal treatment for municipal solid waste, requires expensive air pollution control technologies for polycyclic aromatic hydrocarbons and dioxins, formed as a result of oxidizing conditions [42]. Pyrolysis yields a substantial liquid product, which is more convenient for handling, and has less emissions because less oxygen is present during the process.

\section{Previous Studies of Pyrolysis of Plastics}

Pyrolysis studies using plastic as a feedstock have shown quite high yields of bio-oil with high heating values. Williams and Williams (1999) analyzed oil products from plastic resins and noticed both aliphatic and aromatic compounds in oil products, which have potential use as either fuel or chemical feedstock [43]. Pinto et al. (1999) distilled pyrolysis oil from $\mathrm{PS}$, polypropylene (PP), and polyethylene (PE), and their mixtures, and found that the distillation curves of the oil lie between standard gasoline and gas oil curves; this likely indicates a similarity in oil composition between plastic pyrolysis oil and standard fuels [44]. Onwudili et al. (2009) 
estimated the heating value of oil products from pyrolysis of low-density PE at 450 and $500^{\circ} \mathrm{C}$ to be 40.4 and $40.2 \mathrm{MJ} / \mathrm{kg}$, respectively, comparable to medium fuel oil [45]. Similarly, Lopez et al. (2010) studied pyrolysis of municipal plastic wastes at $500{ }^{\circ} \mathrm{C}$; the authors noted that the oil produced had a high heating value comparable to fossil fuel [46].

According to the United Nations Environmental Programme (2009), only PE, PP, and PS are preferred for conversion into liquid fuel, based on the following criteria: "feeding difficulty to conversion equipment, effective conversion into fuel products, and well-controlled combustion and clean flue gas in fuel user facilities" [47]. Among those three plastics, PS resin is a particularly attractive pyrolysis feedstock because it has the least percent recycled based on municipal solid waste records (EPA, 2009) [38]. Most recycling stations do not accept PS waste because of the uneconomical recycling cost, and the difficulty in finding markets. Furthermore, PS containers that have been used for food are more complicated to recycle because of contamination. Interestingly, PS has quite a high energy content, approximately 16,000 British thermal units (BTUs) per pound, which is twice that of coals [48].

A number of studies have found PS to have the highest oil yield among plastic feedstocks. Williams and Williams (1999) studied pyrolysis of individual plastics and a plastic mixture simulated from the plastic fraction in municipal solid waste of western Europe at

Table 1 Summary of studies of co-pyrolysis of biomass and plastic

\begin{tabular}{|c|c|c|c|c|}
\hline Author (Year) & Biomass & Plastic & Temperature range studied & Result \\
\hline Sharypov et al. (2002) [51] & $\begin{array}{l}\text { Beech wood, pine wood, } \\
\text { cellulose, hydrolytic } \\
\text { lignin }\end{array}$ & $\begin{array}{l}\text { Medium-density PE, } \\
\quad \text { isotactic and atactic PP }\end{array}$ & $400{ }^{\circ} \mathrm{C}$ & $\begin{array}{l}\text { 2x higher light liquid yield than } \\
\text { expected }\end{array}$ \\
\hline Zhou et al. (2006) [52] & Pine wood sawdust & HDPE, LDPE, and PP & Room temperature to $650{ }^{\circ} \mathrm{C}$ & $\begin{array}{l}\text { Approximately } 6-12 \% \text { weight } \\
\text { loss was observed at } 530- \\
650{ }^{\circ} \mathrm{C} \text {, which demonstrated a } \\
\text { synergistic effect at high } \\
\text { temperatures }\end{array}$ \\
\hline Aboulkas et al. (2008) [53] & Olive residue & HDPE & $\begin{array}{l}\text { Room temperature to } \\
1,000^{\circ} \mathrm{C}\end{array}$ & $\begin{array}{l}\text { A } 7-11 \% \text { difference in } \\
\text { experimental and theoretical } \\
\text { weight loss was observed at } \\
450-630{ }^{\circ} \mathrm{C} \text {, indicating a } \\
\text { synergistic effect }\end{array}$ \\
\hline Aboulkas et al. (2009) [54] & Olive residue & LDPE, PP, and PS & $27-1,000{ }^{\circ} \mathrm{C}$ & $\begin{array}{l}\text { Significant interaction around } \\
\quad 400-500{ }^{\circ} \mathrm{C}\end{array}$ \\
\hline $\begin{array}{l}\text { Caglar and Aydinli (2009) } \\
\text { [55] }\end{array}$ & Hazelnut shell & $\begin{array}{l}\text { Ultra-high-molecular- } \\
\text { weight PE }\end{array}$ & $425-650^{\circ} \mathrm{C}$ & $\begin{array}{l}\text { Unusual higher liquid yield as well } \\
\text { as gas products at } 515^{\circ} \mathrm{C}\end{array}$ \\
\hline $\begin{array}{l}\text { Aydinli and Caglar (2010) } \\
\text { [56] }\end{array}$ & Hazelnut shell & PE oxide & $485,515,550,600,650{ }^{\circ} \mathrm{C}$ & $\begin{array}{l}\text { Interaction effect increased oil } \\
\text { yield but not gas yield }\end{array}$ \\
\hline Brebu et al. (2010) [57] & Pine cone & PE, PP, and PS & $500{ }^{\circ} \mathrm{C}$ & $\begin{array}{l}\text { Higher oil yield with lower char } \\
\text { product }\end{array}$ \\
\hline Rutkowski (2009) [58] & Pinewood sawdust & PS and PP & $450{ }^{\circ} \mathrm{C}$ & $\begin{array}{l}\text { Oil compositions were more } \\
\text { comparable to oil produced } \\
\text { from each individual polymer, } \\
\text { with a lower amount of } \\
\text { oxygenated compounds due to } \\
\text { the influence of polymer } \\
\text { addition }\end{array}$ \\
\hline Liu et al. (2013) [59] & Fir sawdust & WEEE & Room temperature to $800^{\circ} \mathrm{C}$ & $\begin{array}{l}\text { Oil yield of } 62.3 \% \text {, which was } \\
\text { significantly higher than those } \\
\text { of either component alone (i.e., } \\
53.1 \% \text { for WEEE and } 46.3 \% \\
\text { for biomass) }\end{array}$ \\
\hline Abnisa et al. (2013) [60] & Palm shell & PS & $400,500,600^{\circ} \mathrm{C}$ & $\begin{array}{l}\text { Max liquid yield of } 68 \% \text { occurred } \\
\text { at } 600{ }^{\circ} \mathrm{C} \text {, palm shell/ } \\
\text { polystyrene ratio of } 40: 60 \text {, and } \\
\text { reaction time of } 45 \mathrm{~min} \text {. The } \\
\text { high heating value of the liquid } \\
\text { was } 40.34 \mathrm{MJ} / \mathrm{kg} \text {, close to that } \\
\text { of conventional fuel oil }\end{array}$ \\
\hline
\end{tabular}

$H D P E$ high-density PE, $L D P E$ low-density PE, $P E$ polyethylene, $P P$ polypropylene, $P S$ polystyrene, $W E E E$ waste electrical and electronic equipment 
$700{ }^{\circ} \mathrm{C}$; oil yields of $80,84,83,84$, and $75 \%$ were reported for high-density PE (HDPE), low-density PE (LDPE), PS, PP, and the mixture, respectively [43]. Pinto et al. (1999) found that pyrolysis of PS yielded the highest liquid product and the lowest gas yield compared with PP, PE, and PS under the same optimum conditions [44]. Siddiqui and Redhwi (2009) conducted pyrolysis of individual LDPE, HDPE, PP, PE, and PS at different temperatures $\left(300-500{ }^{\circ} \mathrm{C}\right)$ [49]. The results showed maximum conversion of PS, which was almost complete. Moreover, PS pyrolysis produced low gas and no insoluble organic matter. Onwudili et al. (2009) studied PS and LDPE pyrolysis between 300 and $500{ }^{\circ} \mathrm{C}$ [45]. The results showed that PS produced an insignificant amount of gas, while LDPE produced higher quantities of gas. Moreover, they found that in pyrolysis of a mixture of LDPE and PS, PS influenced LDPE conversion by lowering degradation temperature and increasing the oil product compared with either individual plastic.

Jung et al. (2013) investigated the influence of various reaction parameters, such as temperature, feed rate, and the type of fluidizing medium on pyrolysis of PS in a fluidized bed reactor. The maximum oil yield was about 87 wt. $\%\left(474{ }^{\circ} \mathrm{C}\right)$. A higher feed rate and the use of product gas as a fluidizing medium were favorable for the oil production [50•].

\section{Co-Pyrolysis of Biomass and Plastics}

Researchers have conducted "co-pyrolysis" with a number of combinations of biomass feedstocks with plastic feedstocks, to enhance oil quantity over biomass alone, as summarized in Table 1. A number of the studies found a higher oil yield than expected based on each individual component. This is possibly owing to an interaction between the product from biomass and polymers in the vapor phase, or the so-called "synergistic effect". The polymers may convert fixed carbon in the biomass into liquid and gas.

Only one study to our knowledge has examined copyrolysis of macroalgae and polystyrene. Kositkanawuth (2012) co-pyrolyzed Sargassum macroalgae and PS at $600{ }^{\circ} \mathrm{C}$ (the optimum temperature identified for pyrolysis of the Sargassum) and four different mixture ratios (5\%, $15 \%, 25 \%$, and $33 \%$ plastic weight) [61•]. Copyrolysis of seaweed and polystyrene improved oil quality by lowering the oxygen content from $9 \%$ to $0.3 \%$, while increasing the carbon content from $74 \%$ to $89 \%$, compared with oil from seaweed alone. The interaction between the seaweed and polymer, however, increased the water-phase product instead of the oil-phase product.
Water elimination of the hydroxyl group in the biomass was the main reaction likely responsible for the higher amount of water and lower oxygen in the oil product. The synergistic effect between the seaweed and PS produced more methane gas, which is beneficial in terms of energy use of the gas. The residue exhibited a low surface area and adsorption capacity; thus, its use as a pollutant adsorbent is not promising. However, it may be able to be used as a fertilizer or soil amendment because it contains significant nitrogen.

\section{Conclusions}

Aquatic biomass, especially algae, is a promising renewable energy resource, owing to its high growth rate, high oil content, and lack of competition with land needed for food crops. Both micro- and macroalgae can be converted to liquid fuel through pyrolysis, with similar thermal behavior. A main drawback of biofuel production using microalgae is its high harvesting costs, owing to its low biomass concentration and small cell size. Using seaweed macroalgae for pyrolysis would reduce problems associated with the seaweed waste disposal in coastal areas. Seaweed pyrolysis has been shown to yield an amount of oil comparable to woody biomass, with similar heating content. Compared to woody biomass, seaweed has been shown to exhibit several potential advantages: lower required temperature, less required energy input owing to exothermic reactions, and fewer phenolic compounds that require deoxygenation for upgrading the oil. However, the high oxygen content of the oil results in a low calorific value compared with fossil fuels.

Co-pyrolysis of biomass with synthetic polymers can improve oil quantity and quality: the polymers are petroleum products, contain less oxygen, and provide a comparable high heating value to conventional fossil fuels. PS is a particularly attractive synthetic polymer, because it has the lowest recycling rate of the major categories of plastic; it also produces a high oil yield compared with other plastics. A number of studies of "co-pyrolysis" of biomass feedstocks with plastic feedstocks have found a "synergistic effect," resulting in a higher oil yield than expected based on each individual component. However, one study of macroalgae and PS co-pyrolysis found that co-pyrolysis increased water yield, not oil yield.

\section{Compliance with Ethics Guidelines}

Conflict of Interest Ketwalee Kositkanawuth, Melanie L. Sattler, and Brian Dennis declare no conflict of interest. 


\section{References}

Papers of particular interest, published recently, have been highlighted as:

- Of importance

1. Demirbas A. Biomass resource facilities and biomass conversion processing for fuels and chemicals. Energy Convers Manag. 2001;42:1357-78.

2. Demirbas A. Analysis of liquid products from biomass via pyrolysis. Energy Source. 2002;24:337-45.

3. Fichtner Consulting Engineers Ltd. The viability of advanced thermal treatment of MSW in the UK. The Environmental Services Training and Education Trust (ESTET), London, United Kingdom, 2004.

4. Astrup T, Bilitewski B. Pyrolysis and gasification. In: Christensen T, editor. Solid waste technology \& management, vol. 1. United Kingdom: John Wiley and Sons, Ltd; 2011.

5. Mckendry P. Energy production from biomass (part 2): conversion technologies. Bioresour Technol. 2002;83:47-54.

6. Zhang L, Xu C, Champagne P. Overview of recent advances in thermo-chemical conversion of biomass. Energy Convers Manag. 2010;51:969-82.

7. Balat M, Kirtay E, Balat H. Main routes for the thermo-conversion of biomass into fuels and chemicals. Part 1: pyrolysis systems. Energy Convers Manag. 2009;50:3147-57.

8. Bridgwater AV, Meier D, Radlein D. An overview of fast pyrolysis of biomass. Org Geochem. 1999;30:1479-93.

9. Moreno-Pirajan JC, Gomez-Cruz R, Garcia-Cuello VS, Giraldo L. Binary system $\mathrm{Cu}(\mathrm{II}) /(\mathrm{Pb}$ (II) adsorption on activated carbon obtained by pyrolysis of cow bone study. J Anal Appl Pyrolysis. 2010;89:122-8.

10. Mullen CA, Boaten AA, Goldberg NM, Lima IM, Laird DA, Hicks $\mathrm{KB}$. Bio-oil and bio-char production from corn cobs and stover by fast pyrolysis. Biomass Bioenergy. 2010;34:67-74.

11. Park HJ, Dong J, Jeon J, Park Y, Yoo K, Kim S, et al. Effects of the operating parameters on the production of bio-oil in the fast pyrolysis of Japanese larch. Chem Eng J. 2008;143:124-32.

12. Jung S, Kang B, Kim J. Production of bio-oil from rice straw and bamboo sawdust under various reaction conditions in a fast pyrolysis plant equipped with a fluidized bed and char separation system. J Anal Appl Pyrolysis. 2008;82:240-7.

13. Heo HS, Park HJ, Park Y, Ryu C, Suh DJ, Suh Y, et al. Bio-oil production from fast pyrolysis of waste furniture sawdust in a fluidized bed. Bioresour Technol. 2010;101:S91-6.

14. Garcia-Perez M, Wang X, Shen J, Rhodes M, Tian F, Lee W, et al. Fast pyrolysis of oil mallee woody biomass: effect of temperature on the yield and quality of pyrolysis products. Ind Eng Chem Res. 2008;47:1846-54.

15. Sensoz S, Kaynar I. Bio-oil production from soybean (Glycine max L.); fuel properties of bio-oil. Ind Crop Prod. 2006;23:99-105.

16. Aguiar L, Marquez-Montesinos F, Gonzalo A, Sanchez JL, Arauzo J. Influence of temperature and particle size on the fixed bed pyrolysis of orange peel residues. J Anal Appl Pyrolysis. 2008;83:124-30.

17. Clarens AF, Resurreccion EP, White MA, Colosi LM. Environmental life cycle comparison of algae to other bioenergy feedstocks. Environ Sci Technol. 2010;44:1813-9.

18. Demirbas A. Use of algae as biofuel sources. Energy Convers Manag. 2010;51:2738-49.

19. Lardon L, Helias A, Sialve B, Steyer J, Bernard O. Life-cycle assessment of biodiesel production from microalgae. Environ Sci Technol. 2009;43(17):6475-81.

20. Wang L, Min M, Li Y, Chen P, Chen Y, Liu Y, et al. Cultivation of Green Algae Chlorella sp. in Different Wastewaters from Municipal
Wastewater Treatment Plant. Appl Biochem Biotechnol. 2010;162: 1174-86.

21. Carlsson AS, Beilen JB, Moller R, Clayton D. In: Bowles D, editor. Micro-and macro- algae: utility for industrial applications. United Kingdom: CPL Press; 2007.

22. Yu LJ, Wang S, Jiang XM, Wang N, Zhang CQ. Thermal analysis studies on combustion characteristics of seaweed. J Therm Anal Calorim. 2008;93(2):611-7.

23. Fox JM. Alternative Uses of Sargassum. Proceedings from Sargassum Symposium 2008, http://www.sargassum.org/ Proceedings2008/Proceedings, accessed June 262011.

24. Li D, Chen L, Yi X, Zhang X, Ye N. Pyrolytic characteristics and kinetics of two brown algae and sodium alginate. Bioresour Technol. 2010;101:7131-6.

25. Anastasakis K, Ross AB, Jones JM. Pyrolysis behaviour of the main carbohydrates of brown macro-algae. Fuel. 2011;90:598-607.

26. Hui Z, Huaxiao Y, Ming L, Congwang Z, Song Q. Pyrolytic characteristics and kinetics of the marine green tide macroalgae, Enteromorpha prolifera. Chin J Oceanol Limnol. 2011;29(5):9961001.

27. Kim SS, Ly HV, Kim J, Choi JH, Woo HC. Thermogravimetric characteristics and pyrolysis kinetics of Alga Sargassum sp. biomass. Bioresour Technol. 2013;139:242-8.

28. Zhao H, Yan HX, Liu M, Sun BB, Zhang Y, Dong SS, et al. Production of Bio-oil from Fast Pyrolysis of Macroalgae Enteromorpha prolifera Powder in a Free-fall Reactor. Energy Sources Part A Recover Utilization Environ Eff. 2013;35(9):85967.

29. Wang S, Jiang XM, Wang N, Yu LJ, Li Z, He PM. Research on pyrolysis characteristics of seaweed. Energy Fuel. 2007;21:3723-9.

30. Ross AB, Jones JM, Kubachi ML, Bridgeman T. Classification of macroalgae as fuel and its thermochemical behaviour. Bioresour Technol. 2008;99:6494-504.

31. Bae YJ, Ryu C, Jeon J, Park J, Suh DJ, Suh Y, et al. The characteristics of bio-oil produced from the pyrolysis of three marine macroalgae. Bioresour Technol. 2011;102:3512-20.

32. Trinh TN, Jensen PA, Dam-Johansen K, Knudsen NO, Sorensen HR, Hvilsted S. Comparison of lignin, macroalgae, wood, and straw fast pyrolysis. Fuels. 2013;27(3):1399-409. Study compares product distribution and energy recoveries from several pyrolysis feedstocks, including macroalgae.

33. Kebelmann K, Hornung A, Karsten U, Griffiths G. Thermo-chemical behaviour and chemical product formation from Polar seaweeds during intermediate pyrolysis. J Anal Appl Pyrolysis. 2013;104:131-8.

34. Hu Z, Zheng Y, Yan F, Xiao B, Liu S. Bio-oil production through pyrolysis of blue-green algae blooms (BGAB): Product distribution and bio-oil characterization. Energy. 2013;52:119-25. Study of the impact of several pyrolysis operational variables on macroalgae product distribution and bio-oil properties.

35. Ferrera-Lorenzo N, Fuente E, Suarez-Ruiz I, Gil RR, Ruiz B. Pyrolysis characteristics of a macroalgae solid waste generated by industrial production of Agar-Agar. J Anal Appl Pyrolysis. 2014;105:209-16

36. Kan T, Grierson S, de Nys R, Strezov V. Comparative assessment of the thermochemical conversion of freshwater and marine microand macroalgae. Energy Fuels. 2014;28(1):104-14.

37. U.S. Environmental Protection Agency (EPA). "Plastics." http:// www.epa.gov/epawaste/conserve/materials/plastics.htm, accessed on 15 Jan 2011.

38. U.S. Environmental Protection Agency (EPA). "Municipal solid waste generation, recycling, and disposal in the United States: Detailed tables and figures for 2008." Office of Resource Conservation and Recovery, 2009.

39. Azapagic A, Emsley A, Hamerton I. Polymers, the environment and sustainable development. England: John Wiley \& Sons, Ltd.; 2003. 
40. Lazarevic D, Aoustin E, Buclet N, Brandt N. Plastic waste management in the context of a European recycling society: comparing results and uncertainties in a life cycle perspective. Resour Conserv Recycl. 2010;55:246-59.

41. Gu R, Lee, O, Salehzadah Y. An Investigation into Polystyrene Recycling at UBC. Dawn Mills, APSC 262, The University of British Columbia, 2010.

42. Vehlow J, Dalager S. Incineration: flue gas cleaning and emissions. In: Christensen TH, editor. Solid waste technology \& management. Wiley: Chichester, West Sussex, U.K; 2011.

43. Williams EA, Williams P. The pyrolysis of individual plastics and a plastic mixture in a fixed bed reactor. J Chem Technol Biotechnol. 1997;70:9-20.

44. Pinto F, Costa P, Gulyurtlu I, Cabrita I. Pyrolysis of plastic wastes. 1. Effect of plastic waste composition on product yield. J Anal Appl Pyrolysis. 1999;51:39-55.

45. Onwudili JA, Insura N, Williams PT. Composition of products from the pyrolysis of polyethylene and polystyrene in a closed batch reactor: effects of temperature and residence time. J Anal Appl Pyrolysis. 2009;86:293-303.

46. Lopez A, Marco I, Caballero BM, Laresgoiti MF, Adrados A. Pyrolysis of municipal plastic wastes: influence of raw material composition. Waste Manag. 2010;30:620-7.

47. United Nations Environmental Programme (UNEP). Converting waste plastics into a resource, Compendium of Technologies. Division of Technology, Industry and Economics International Environmental Technology Centre Osaka/Shiga, Japan, 2009.

48. American Chemistry Council. Take a closer look at today's polystyrene packaging. http://www.americanchemistry.com/s_ACC/ sec_article.asp? $\mathrm{CID}=65 \& \mathrm{DID}=7213 \&$ dowhat $=\& \mathrm{css}=$ print, accessed on 15 Jan 2011.

49. Siddiqui MN, Redhwi HH. Pyrolysis of mixed plastics for the recovery of useful products. Fuel Process Technol. 2009;90:54552.

50. Jung SH, Kim SJ, Kim JS. The influence of reaction parameters on characteristics of pyrolysis oils from waste high impact polystyrene and acrylonitrile-butadiene-styrene using a fluidized bed reactor. Fuel Process Technol. 2013;116:123-9. Study of the influence of various reaction parameters on pyrolysis of polystyrene.
51. Sharypov VI, Marin N, Beregovtsova NG, Baryshnikov SV, Kuznetsov BN, Cebolla VL, et al. Co-pyrolysis of wood biomass and synthetic polymer mixtures. Part I: influence of experimental conditions on the evolution of solids, liquids, and gases. J Anal Appl Pyrolysis. 2002;64:15-28.

52. Zhou L, Wang Y, Huang Q, Cai J. Thermogravimetric characteristics and kinetic of plastic and biomass blends co-pyrolysis. Fuel Process Technol. 2006;87:963-9.

53. Aboulkas A, El Harfi K, El Bouadili A, Nadifiyine M, Benchanaa M, Mokhlisse A. Pyrolysis kinetics of olive residue/plastic mixtures by non-isothermal thermogravimetry. Fuel Process Technol. 2009;90:722-8.

54. Aboulkas A, El Harfi K, Nadifiyine M, El Bouadili A. Thermogravimetric characteristics and kinetic of co-pyrolysis of olive residue with high density polyethylene. J Therm Anal Calorim. 2008;91(3):737-43.

55. Caglar A, Aydinli B. Isothermal co-pyrolysis of hazelnut shell and ultra-high molecular weight polyethylene: the effect of temperature and composition on the amount of pyrolysis products. J Anal Appl Pyrolysis. 2009;86:304-9.

56. Aydinli B, Caglar A. The comparison of hazelnut shell co-pyrolysis with polyethylene oxide and previous ultra-high molecular weight polyethylene. J Anal Appl Pyrolysis. 2010;87:263-8.

57. Brebu M, Ucar S, Vasile C, Yanik J. Co-pyrolysis of pine cone with synthetic polymers. Fuel. 2010;89:1911-8.

58. Rutkowski P. Influence of zinc chloride addition on the chemical structure of bio-oil obtained during co-pyrolysis of wood/synthetic polymer blends. Waste Manag. 2009;29:2983-93.

59. Liu WJ, Tian K, Jiang H, Zhang XS, Yang GX. Preparation of liquid chemical feedstocks by co-pyrolysis of electronic waste and biomass without formation of polybrominated dibenzo-p-dioxins. Bioresour Technol. 2013;128:1-7.

60. Abnisa F, Wan Daud WMA, Ramalingam S, Azemi MNBM, Sahu JN. Co-pyrolysis of palm shell and polystyrene waste mixtures to synthesis liquid fuel. Fuel. 2013;108:311-8.

61. Kositkanawuth K. Investigation of the co-pyrolysis between Sargassum macroalgae and polystyrene. Ph.D. Dissertation, University of Texas at Arlington, 2012. The only study to examine co-pyrolysis of macroalgae and polystyrene. 